\title{
The Battle of Brooklyn: World City and Space of Neighborhoods
}

\author{
Benjamin Shepard ${ }^{1}$
}

Throughout Brooklyn, regular people are fighting off the negative dynamics of urban experience, including uneven development, speculative gentrification, displacement, and police brutality long seen in global cities. Yet, little of the global cities literature considers the ways local actors impact global forces shaping world cities. Instead, observers of globalization suggest local actors have been relegated the sidelines as passive spectators of larger social and economic forces. Many wonder, is there a space for agency in global cities? Can regular people shape the dynamics of life in cities? For many, the answer is clearly affirmative. Throughout the borough of Brooklyn, people are coping with the underside of globalization by creating viable alternatives. Could studying the Brooklyn experience offer some insight into efforts to cope with globalization? Throughout six case studies - on rezoning, eviction defense, a battle against a big box chain store, for a bike lane, a local business, and against police brutality- Brooklyn is viewed as a space which contends with the forces impacting globalization and uneven development in surprising and innovative ways. [Article copies available for a fee from The Transformative Studies Institute. E-mail address: journal@transformativestudies.org Website: http://www.transformativestudies.org (C2013 by The Transformative Studies Institute. All rights reserved.]

KEYWORDS: Global Cities, Uneven Development, Activism, Globalization.

\footnotetext{
${ }^{1}$ Benjamin Shepard, PhD, LMSW, is an Assistant Professor of Human Services at City Tech/CUNY. He is also the author/editor of six books: White Nights and Ascending Shadows: An Oral History of the San Francisco AIDS Epidemic (1997), From ACT UP to the WTO: Urban Protest and Community Building in the Era of Globalization (2002), Queer Political Performance and Protest (Routledge, 2009) The Beach beneath the Streets: Contesting New York's Public Spaces (with Greg Smithsimon, SUNY Press) and Play, Creativity, and Social Movements: If I Can't Dance, Its Not My Revolution (Routledge, 2011). Address correspondence to: Benjamin Shepard, New York City College of Technology/ CUNY, 300 Jay Street, Brooklyn, NY 11201; e-mail: bshepard@citytech.cuny.edu; tel: 9175867952.
} 